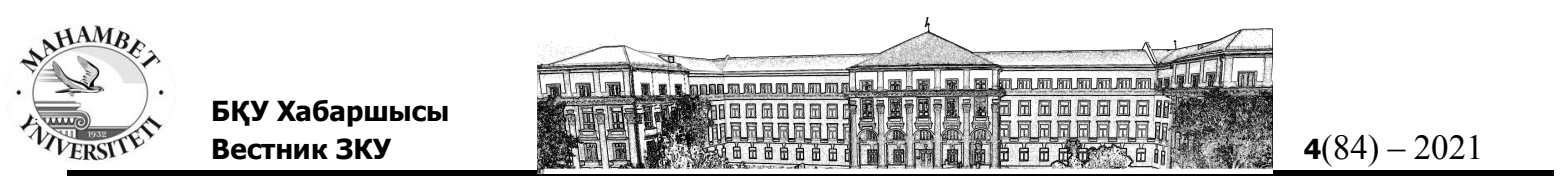

UDC 581.527

IRSTI 34.15 .25

DOI 10.37238/1680-0761.2021.84(4).53

\author{
Kozhagalieva Rima, Sungatova Shattyk* \\ M.Utemisov West Kazakhstan University, Uralsk, Kazakhstan \\ *Correspondence: shakonni@mail.ru
}

E-mail: shakonni@mail.ru

\title{
FEATURES OF THE POPULATION OF NELUMBO NUCIFERA DISTRIBUTED IN THE LOWER REACHES OF THE KIGACH RIVER, ATYRAU REGION
}

Annotation. In the article presented to the publication, the biological features and adaptations of the population of Nelumbo Nucifera found in the Kigach River, Atyrau region are determined and the results of phenological studies are presented. In recent years, due to the increase in coastal settlements, places of production and Recreation, the natural environment is changing dramatically. In this regard, the main goal of our work is to analyze the features of adaptation and phenological indicators of the population of Nelumbo Nucifera whose productivity has increased in recent years. The percentage of vegetation cover of this amazing lotus, which is found in the kigach River, describes the vegetation cover of the tiers. In the future, it is relevant to preserve and protect this world of flora. The living conditions of this plant Nelumbo Nucifera, listed in the Red Book of Kazakhstan, are at a good level. Because every year it blooms and grows. The study found out why Nelumbo Nucifera appeared in the Kigach River, Atyrau region. It has been shown that in natural conditions it is rarely propagated by seeds, and renewal occurs vegetatively. As a result of phenological studies, we were convinced that the Lotus found in the kigach River is actually an endemic species, a rare plant. Therefore, with this in mind, the authors propose to conduct monitoring of the plant Nelumbo Nusifera thereby keeping the state of the population under control.

Keywords: phenological research; population; tier; geographical analysis; environmental analysis; life form; population; adaptation; phenological phases.

\section{Introduction}

Biological diversity is the result of long-term evolution of organic life. It is preservation is the most important task of Environmental Protection, since changes in the environment lead to changes in the biota. The preservation of Natural Resources and Biological Diversity is a national task, as well as the preservation of the diversity of natural flora is one of the most pressing problems of our time. The main feature of each Flora is its species composition, accounting for the species of plants that grow in a certain territory, i.e. the creation of a flora inventory is the basis of each research paper. The main reason for the actual loss of biodiversity is the destruction and degradation of the habitat, and most importantly, deforestation, soil erosion, pollution of inland and marine reservoirs, excessive consumption of plant and animal species. Based on this, Kazakhstan adopted the "Fourth report on Biological Diversity" in 2008. The report pays special attention to the study of rare and endangered plants and shrubs. Because the human impact on the environment is growing from year to year, and the world community is beginning to understand the need to preserve biological diversity. Today, at the initiative of professors and teachers of the Department of Biology and Ecology of the M. Utemisov West Kazakhstan University, studies of rare endemic and relict species at the population level have been conducted recently. Not so long 


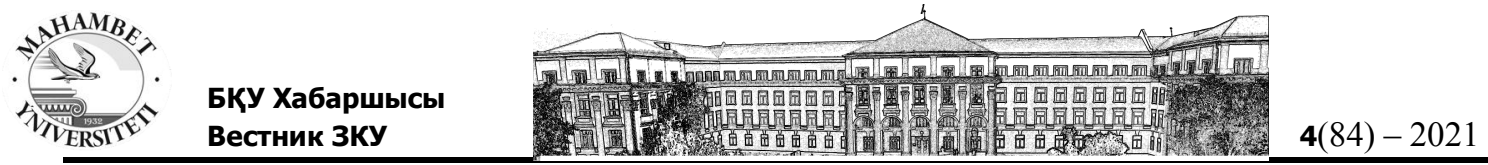

ago, the habitat of alien species of plants and animals was also recognized as an alarming condition for biodiversity loss.

The Kigach River, located near the city of Atyrau, is a landmark that can attract tourists, residents and guests of the city. The plant world is diverse, interesting and protected, characterized by endemic and relict species that are of great interest. One of them is Nelumbo Nucifera. In geobotanical, phytomorphological and phytoecological, phenological studies, the study of the Nelumbo Nucifera community is important. The of the study is to find out why the species was adapted to the city of Atyrau among the cities of Kazakhstan and conduct phenological studies. The results of such works were used in the formation of a complex description of plant communities, species and the identification of plant life forms, which allowed us to further expand our knowledge of the study of plant biology. There are many reservoirs, lakes and small reservoirs in the country. There fore, comprehensive studies of reservoirs can be carried out to determine their current state and economic significance for the fields of hydrobiology, hydrology, and hydrochemistry $[1,459 \mathrm{p}]$.

\section{Materials and methods}

The plant we studied was Nelumbo Nucifera an endemic species distributed in the Kigach River, Atyrau region, which is rare in the flora of Kazakhstan. Research work on the water areas where this species is located was carried out in the summer of 2021. When studying the phenological characteristics of the plant Nelumbo Nucifera we used traditional approaches that are widely used in geobotany [2]. The area where we conducted the research is located at a distance of $1553 \mathrm{~m}$ from Kurmangazy district. The coordinates of the Lotus Valley were determined using the JPS Navigator GARMIN GPS MAP 60 CSx. In the course of our research, we have described the number of encounters in this valley, where the communities we encounter are acquainted with the species of dominant plants. We used the reference books "Flora of Kazakhstan", 4 volumes of which were published in 1961 [3]. During the study of plant species collected in 2 volumes «Illustrated surveyor of Kazakhstan» volume I-1969, volume II-1972 [4, 25]. The classification of species depending on life forms was carried out according to the work of I. G. Serebryakov in 1962 [5, 378 p]. The results were processed using the MC-300 video TEC program for cross-sections of the lesson. The studied Nelumbo Nucifera began to be found around 2016. As a reason for the occurrence of this species in this region, the settlement of Astrakhan is located nearby. Nelumbo Nucifera is very common in this locality. In this regard, we concluded that the seeds came through the water. The research area was visited and analyzed in May, June, July, and August. When we visited the region where the study was conducted in May, we found that the vegetative period began, and when we visited in June, Nelumbo Nucifera grew and increased productivity. Phenological analysis of N. I. We conducted according to the Beideman method [6,333 p]. The temperature of the air, the surface area of the water, the acidity of the water, and the depth were measured by the thickness of the sediment at the bottom of the water. The empty surface of the water in the lake described its area. The projective coating of $10 \mathrm{~m}^{2}$, the number of leaves, morphometric characteristics of fruits and berries were given. In the study of the seed yield of the species, the method of I. V. Vainagia was used [7, $826 \mathrm{p}]$. The yield of mature fruits was at a high level. The following indicators were determined: the actual yield of fruits, the number of ripe seeds, data on the yield of seeds were developed using the mathematical statistics method M-arithmetic mean, m-its error, V-coefficient of variation using the EXCEL computer program.

\section{Research results and their analysis}

According to the results of our 2021 study, the area of the local population of Nelumbo Nucifera was about $16000 \mathrm{~m}^{2}$. We came to the conclusion that the ratio of the Lotus and the smooth surface of the reservoir is 1:3. Nelumbo Nucifera forms monodominant cenoses. Before the development of the Lotus, the first blue-green algae species Trapella sinensis Oliv and Ceratophyllum demereum invaded the surface of the water. The Lotus slope was concentrated on the southern and south-eastern banks of the river. The water depth was $0.5-1 \mathrm{~m}$ the bottom 
sediments were $15-20 \mathrm{~cm}$ the $\mathrm{pH}$ of the water was 5.5 medium acidity. It was found that the KOA community dominates the Nelumbo Nucifera Valley. The main components of the community were the following species. These are: black koi Typha, Reed Phragmites, chengel Halimodendron. Among the above-mentioned species, some dominant species have become the objects of our research. In the coastal part of the Nelumbo Nucifera region of the kigach River, a grove is formed, forming a thin intermittent strip. It is clear that the vegetation of these associations is arranged in five tiers. Phragmites of the first tier made up $80 \%$ of the Lotus valley, with a height of $1-1.5 \mathrm{~m}$ the terrain is flat with a slope to the north. The perennial Koa Typha of the II tier forms a height of $2 \mathrm{~m}$. Chengel Halimodendron of the III Tier reaches 0-2 or 3 meters. The lowest tier of the IV was formed by steel herbaceous plants with a height of 10-15 cm. The dominant species was the typha community. It is close to any area of the forest, especially in the coastal zone, surpassing other plant species in terms of quantitative indicators. We determined the frequency of occurrence of Elaegnus oxycapra schelecht from trees. Nelumbo Nucifera, a nut-shaped Lotus belonging to the Nelumbonaceae family, often reproduces due to the fact that the rhizomes grow annually. It is considered a deep-water plant, the roots are completely submerged in a swampy area of water, very densely located. We found that the Lotus is an endemic plant, there are 3 types of leaves: underwater, surface, and above the surface of the water. The stems are very thick with a length of 22. 5 m.the Tubular stems reach several meters, depending on the depth of the pond. The roots are the part that stores nutrients used in the process of vegetative reproduction.

The projective coverage of the studied Lotus population was about $90-100 \%$. The number of leaves floating on the surface of the water exceeds the number of leaves floating on the surface of the water. That is, the quantitative predominance of these variable leaves indicates that the yield of Nelumbo Nucifera is at a good level. The water surface of Nelumbo Nucifera leaves contributes to the process of photosynthesis, allowing more organic matter to be released into the air. The number of generative organs of the flower was observed on the surface of the water approximately the same buds, flowers and fruits. That is, it can be understood that the generative phase of the plant Nelumbo Nucifera proceeds intensively. We observed the beginning and duration of the vegetative and generative phases of Lotus near the Kigach River, Atyrau region. The dynamics of the distribution of lotus is not the same throughout the year. Despite the fact that the concentration of pollutants increases in the spring and summer months, the degree of purity of the Kigach River, where this population is located, is quite high. The percentage of vegetation cover of this amazing lotus, which is found in the Kigach river, describes the vegetation cover of the tiers. Because every year it blooms and grows.

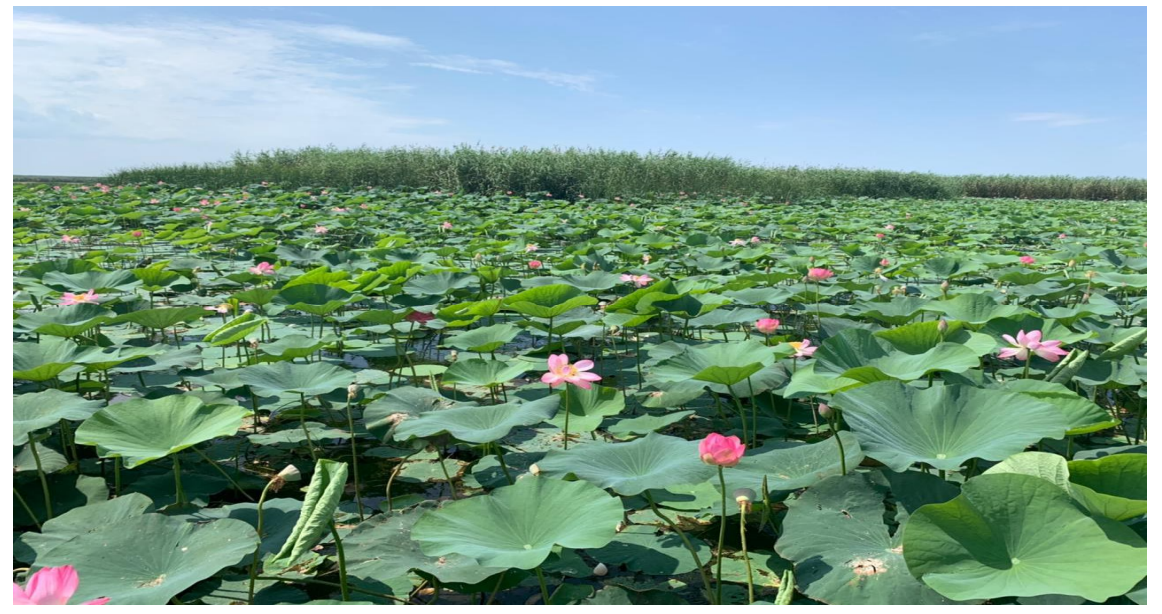

Figure 1 - The plant Nelumbo Nucifera in the research area during the growing season in June 
As it turned out, during the growing season, this population develops in different phases. The longest phase is the flowering and fruiting periods. According to the results of the 2021 study, from the growing season, flowering and fruiting lasts 73 days. In our study, the flowering period begins when the daytime air temperature and water surface temperature are above $20^{\circ} \mathrm{C}$, and the transition to a calm state is below $10^{\circ} \mathrm{C}$. The process of mass flowering in the population we have tested begins in June and continues until the end of August. Thus, it stops its life cycle in case of adverse temperatures. Thus, the productivity property in the studied region is significantly higher.

\section{Conclusion}

Thus as a result of geobatanical and phenological studies of the population of the endemic species Nelumbo Nucifera found in the confluence of the Kigach river, we were convinced that it is actually a rare plant. This species is located near the water in the floodplain of the river, there is enough moisture, and the sun gets better. Thus, phenological studies were conducted and we determined the process of adaptation. Conservation of the species is very important for the environment. The lotus plant reproduces mainly vegetatively, through its roots, and the ecology of the Kigach river creates conditions for the distribution of this population. This was confirmed by studying the roots of this population. In the course of the conducted studies, we achieved the following result: growing season - budding - flowering - full growth - end of the growing season rest we observed the stages of development. The long flowering period of the population was about 3 months. We found that the temperature indicators of air and water affect the onset of phenophases. In order for the flowering period to begin, it is important that the air and water surface temperature starts from $20^{\circ} \mathrm{C}$. We realized that performance shows a lower indicator than bad weather. According to morphometric indicators, we estimate that the vegetative and generative periods showed high results in the population of Nelumbo Nucifera. In the near future, phenological studies of species found in different countries for the Nelumbo Nucifera community will be conducted and analyzed. In conclusion, it is necessary to promote the spread of the population of the rare endemic Nelumbo Nucifera to other localities in Kazakhstan. The object of the article is that the population of Nelumbo Nucifera has a significant share in our tourism sector. Therefore, as a result of these studies, the development and implementation of a comprehensive program for their protection is the main guarantee of preserving the country's biodiversity. We hope that in the future, the areas of the object studied by Nelumbo Nucifera will become one of the tourist centers.

\section{REFERENCES}

[1] Zlobin, Yu.A., Sklyar, V.G., \& Klimenko, A.A. (2013). Populiatsii redkikh vidov rastenii. Teoreticheskie osnovy i metodika izucheniia [Populations of rare plant species. Theoretical foundations and methods of study]. Sumy [in Russian]

[2] Mukhitdinov N.M., Karasholakova L.N., Kurmanbayeva M.S. (2014) The number and the age structure of rare endemic species cenopopulation Lonicera iliensis Pojark, Life Science Journal. Vol. 11, Iss. 6. - P. 459-463 [in English]

[3] Flora Kazakhstana [Flora of Kazakhstan] (1961). Vol. 4. Alma-Ata. P-25 [in Russian]

[4] Illiustrirovannyi opredelitel rastenii Kazakhstana [Illustrated determinant of plants of Kazakhstan]. (1969-1972). Vols. 1. Alma-Ata: Nauka [in Russian]

[5] Serebryakov I. G. (1962) Ecological morphology of plants. Moscow: Higher School, p $-378$

[6] Beideman I. N. (1960) Izuchenie fenologii rastenij [The study of phenology of plants] E. M. Lavrenko, A. A. Korchagin (Ed.). Polevaya geobotanika. - M. ANSSSR. Vol. V. Iss.II. - P. 333-348 [in Russian]

[7] Vainagiy I. V. (2015) O metodike izuchenija semennoj produktivnosti rastenij [On the methodology of studying seed productivity of plants]. Botan. journal. Vol. 59, 6. P. 826- [in Russian] 


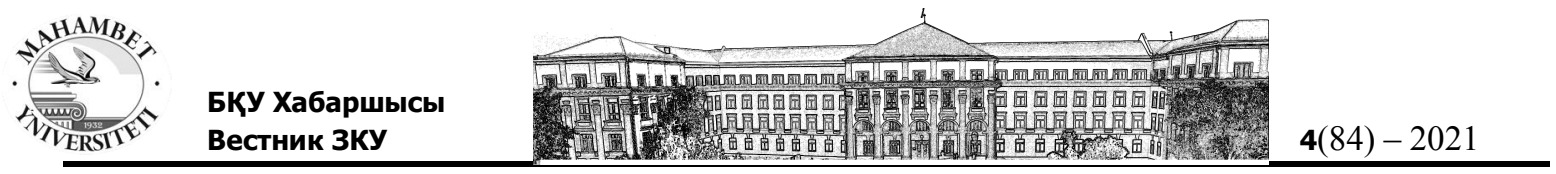

Кожагалиева Р.Ж., Сунгатова Ш.Р.

\section{АТЫРАУ ОБЛЫСЫ, ҚИҒАШ ӨЗЕНІНІН ТӨМЕНГІ \\ АҒЫСЫНДА ТАРАЛFАН NELUMBO NUCIFERA \\ ПОПУЛЯЦИСЫНЫН ЕРЕКШЕЛІКТЕРІ}

Андатпа. Жариялымға ұсынылған мақалада Атырау облысының Қиғаш өзенінде таралған Nelumbo Nucifera популяциясының биологиялық ерекшеліктері мен бейімделуі анықталды және фенологиялық зерттеулердің нәтижелері ұсынылды. Соңғы жылдары жағалаудағы елді мекендердің, өндіріс және демалыс орындарының ұлғаюына байланысты табиғи орта күрт өзгеруде. Осыған байланысты біздің жұмысымыздың негізгі мақсаты соңғы жылдары өнімділігі артқан Nelumbo Nucifera популяциясының бейімделу ерекшеліктері мен фенологиялық көрсеткіштерін талдау. Болашақта бұл флора әлемін сақтау және қорғау маңызды. Қазақстанның Қызыл кітабына енгізілген Nelumbo Nucifera өсімдігінің тіршілік ету жағдайы жақсы деңгейде. Себебі ол жыл сайын гүлдейді және өнімділігі артып келе жатыр. Зерттеу барысында Nelumbo Nucifera Атырау облысының Қиғаш өзенінде неге пайда болғандығы анықталды. Табиғи жағдайда ол тұқыммен сирек таралады, ал жаңару вегетативті түрде жүреді. Фенологиялық зерттеулердің нәтижесінде біз Кигаш өзенінен табылған лотос іс жүзінде эндемикалық түр, сирек кездесетін өсімдік екеніне көз жеткіздік. Сондықтан, осыны ескере отырып, авторлар Nelumbo Nucifera өсімдігін бақылауды ұсынады, осылайша популяцияның жағдайын бақылайды.

Кілт сөздер: фенологиялық зерттеулер; популяция; ярус; географиялық талдау; экологиялық талдау; өмір сүру түрі; популяция; бейімделу; фенологиялық фазалар.

\section{Кожагалиева Р.Ж., Сунгатова Ш.Р. ОСОБЕННОСТИ ПОПУЛЯЦИИ NELUMBO NUCIFERA, РАСПРОСТРАНЕННОЙ В НИЗОВЬЯХ РЕКИ КИГАШ АТЫРАУСКОЙ ОБЛАСТИ}

Аннотация. В представленной к публикации статье выявлены биологические особенности и адаптация популяции Nelumbo Nucifera распространенной в реке Кигаш Атырауской области, и представлены результаты фенологических исследований. В последние годы природная среда резко меняется из за увеличения прибрежных поселений, производственных и рекреационных зон. В связи с этим основной целью нашей работы является анализ адаптационных особенностей и фенологических показателей популяции Nelumbo Nucifera, продуктивность которой в последние годы возросла. В дальнейшем важно сохранить и защитить этот мир флоры. Условия обитания растения Nelumbo Nucifera занесенного в Красную книгу Казахстана, находятся на хорошем уровне. Потому что он цветет каждый год и урожайность растет. В ходе исследования было установлено почему Nelumbo Nucifera возникла на реке Кигаш в Атырауской области. В естественных условиях размножается семенами редко, а возобновление происходит вегетативно. В результате фенологических исследований мы убедились, что лотос, найденный в реке Кигаш, на самом деле является эндемичным видом, редким растением. Поэтому, учитывая это, авторы рекомендуют наблюдать за растением Nelumbo Nucifera тем самым контролируя состояние популяции.

Ключевые слова: фенологические исследования; популяция; ярус; географический анализ; экологический анализ; форма жизни; популяция; адаптация; фенологические фазы. 